\title{
Pengaruh Profesionalisme, Indepensi, dan Kompetensi Auditor terhadap Kualitas Audit di Badan Pendapatan Pengelolaan Keuangan dan Aset Daerah
}

\author{
Khoirun Nisa Imami \\ Program Studi Akuntansi Syariah, Fakultas Ekonomi dan Bisnis Islam, IAIN Madura, Indonesia \\ Email: khoirunnisaimami@gmail.com \\ Farahdilla Kutsiyah \\ Program Studi Perbankan Syariah, Fakultas Ekonomi dan Bisnis Islam, IAIN Madura, Indonesia \\ Email: keindahanmaduraku@gmail.com \\ Ira Hasti Priyadi \\ Program Studi Akuntansi Syariah, Fakultas Ekonomi dan Bisnis Islam, IAIN Madura, Indonesia \\ Email: irahastipriyadi@iainmadura.ac.id
}

\begin{abstract}
:
This study uses quantitative approach with three independent variables those are professionalism, independence, and competence, and auditing is as one dependent variable. The sampling of this study is 30 respondents which were at Regional Financial and Asset Management Revenue Agency, Sumenep Regency and using multiple linear analysis. The kind of data used was primer data that was questionnaire. The data analysis of this study used IBM SPSS Statistic 20 software. The results of this study showed: firstly, partially professionalism did not significantly influence on the quality of auditing with t-value $-0,573<$ t-table 2,056 and significantly $0,572>0,05$. Partial Independence influence on the quality of auditing with $t-$ value 2,116 $>$ t-table 2,056 and significant $0,044<0,05$. Partially competence influence on the quality of auditing with t-value 2,116 $>\mathrm{t}$-table 2,056 and significant $0,044<0,05$. Secondly, professionalism, independence and competence were simultaneously influence on the quality of auditing with t-value 10,341 >t-table 2,96. Thirdly, the quality of auditing was influence by professionalism, independence, and competence only as big as $54,4 \%$ while the remainder $45,6 \%$ was influenced by other variables that was not studied in this research.
\end{abstract}

Keywords: The Quality of audit, Accounting

\begin{abstract}
Abstrak:
Penelitian ini menggunakan pendekatan kuantitatif dengan tiga variabel independen yakni profesionalisme, independensi dan kompetensi serta satu variabel dependen yakni kualitas audit. Sampel dalam penelitan ini yaitu 30 responden yang berada di Badan Pendapatan Pengelolaan Keuangan dan Aset Daerah Kabupaten Sumenep dan menggunakan analisis linier berganda. Jenis data yang digunakan adalah data primer yaitu penyebaran kuesioner. Analisis data dalam penelitian ini menggunakan software IBM SPSS Statistic 20. Hasil penelitian ini menunjukkan bahwa: Pertama, profesionalisme secara parsial tidak berpengaruh terhadap kualitas audit dengan $t_{\text {hitung }}-0,573<t_{\text {tabel }} 2,056$ dan signifikansi $0,572>0,05$. Indepedensi secara parsial berpengaruh terhadap kualitas audit dengan $t_{\text {hitung }} 2,088>t_{\text {tabel }} 2,056$ dan signifikan 0,047 $<0,05$. Kompetensi secara parsial berpengaruh terhadap kualitas audit dengan $t_{\text {hitung }} 2,116>t_{\text {tabel }} 2,056$ dan signifikan $0,044<0,05$. Kedua, profesionalisme, indepedensi dan kompetensi secara simultan berpengaruh terhadap kualitas audit dengan $\mathrm{f}_{\text {hitung }} 10,341>\mathrm{f}_{\text {tabel }} 2,96$. Ketiga, kualitas audit dipengaruhi oleh profesionalisme, indepedensi
\end{abstract}


Khoirun Nisa Imami, Farahdilla Kutsiyah, Ira Hasti Priyadi

dan kompetensi hanya sebesar $54,4 \%$ sedangkan sisanya $45,6 \%$ dipengaruhi oleh variabel lain yang belum diteliti dalam penelitian ini.

Kata Kunci: Kualitas Audit, Akuntansi 


\section{PENDAHULUAN}

Laporan keuangan merupakan catatan informasi keuangan suatu perusahaan pada suatu periode akuntansi yang dapat digunakan untuk menggambarkan kinerja perusahaan. Laporan akuntansi disiapkan untuk memberikan informasi yang berguna bagi para pemakai laporan (users), terutama sebagai dasar pertimbangan dalam proses pengambilan keputusan kelak. Laporan akuntansi ini dinamakan laporan keuangan. ${ }^{1}$ Laporan keuangan menjadi salah satu bentuk bentuk pertanggungjawaban manajemen yang dapat memberikan informasi yang sangat berguna bagi para pengguna dalam pengambilan keputusan. Oleh karena itu, laporan keuangan yang disajikan harus relevan dan dapat diandalkan.

Para pemakai informasi menggunakan jasa auditor eksternal untuk mengukur karakteristik yang dibutuhkan dan memberikan jaminan bahwa laporan keuangan yang dibuat oleh manajemen relevan dan dapat diandalkan sehingga dapat meningkatkan kepercayaan semua pihak yang berkepentingan. ${ }^{2}$ Auditor mendapat kepercayaan dari klien dan pihak-pihak lain untuk membuktikan kewajaran laporan keuangan yang disajikan oleh klien. Laporan keuangan yang telah di buat perlu diaudit oleh auditor eksternal karena laporan keuangan kemungkinan mengandung kesalahan baik yang disengaja maupun yang tidak disengaja. ${ }^{3}$

Besarnya kepercayaan pengguna laporan keuangan pada akuntan publik ini mengharuskan akuntan publik memperhatikan profesionalismenya yang akan mempengaruhi kualitas auditnya. Profesionalisme merupakan suatu keharusan bagi seorang auditor dalam menjalankan tugasnya. Profesionalisme seorang profesional akan semakin penting apabila profesionalsime dihubungkan dengan hasil kerja individunya sehingga pada akhirnya dapat memberi keyakinan bekerja. Oleh karena itu, auditor dituntut untuk profesional dalam setiap tugasnya, auditor yang memiliki pandangan profesionalisme yang tinggi akan memberikan kontribusinya yang dapat dipercaya oleh para pengambil keputusan. ${ }^{4}$

Seorang auditor juga membutuhkan sikap yang independen dalam mematuhi kode etik yang sudah ditetapkan demi mendapatkan kualitas audit yang baik. Auditor harus memegang teguh independensinya sehinga dapat melakukan audit dengan baik. Auditor harus memiliki sikap netral dan tidak bias serta menghindari konflik kepentingan dalam merencanakan, melaksanakan dan melaporkan pekerjaan yang dilakukan. Jika independensi dari auditor terganggu maka dapat mempengaruhi kualitas dari hasil audit.

Seorang auditor harus mempunyai keahlian dan kompetensi terlebih dahulu sebelum dapat menjadi independen karena seorang auditor yang tidak kompeten tidak mungkin dapat bertindak independen dalam melaksanakan tugas auditnya. Auditor yang tidak berkompeten cenderung bergantung pada pendapat orang lain dalam menyelesaikan tugas auditnya karena keterbatasan pengetahuan dan keahlian yang dimiliki. ${ }^{5}$

\footnotetext{
${ }^{1}$ Hery, 240 Konsep Penting Akuntansi Dan Auditing (yogyakarta: Gava Media, 2013), hlm. 4.

${ }^{2}$ Fietoria, Elisabeth Stefany, "Pengaruh Profesionalisme, Independensi, Kompetensi, Dan Pengalaman Kerja Terhadap Kualitas Audit Di Kantor Akuntan Publik Bandung."Journal of Accounting and Business Studies, 1 (September, 2013) hlm., 20.

${ }^{3}$ Mulyadi, Auditing (Jakarta: PT. Salemba Empat, 2002), hlm. 162.

${ }^{4}$ Lauw Tjun, Elyzabet indrawati, santy setiawan, "Pengaruh Indepedensi dan Kompetensi AuditorTerhadap kualitas Audit.”Jurnal Akuntansi, 1 (Mei, 2012) hlm., 34

${ }^{5}$ Fietoria, Elisabeth Stefany, "Pengaruh Profesionalisme, Independensi, Kompetensi, Dan Pengalaman Kerja Terhadap Kualitas Audit Di Kantor Akuntan Publik Bandung.”Journal of Accounting and Business Studies, 1 (September, 2013) hlm., 21.
} 
Auditor dalam melaksanakan audit harus bertindak sebagai seorang ahli dalam bidang akuntansi dan auditing. Pencapaian keahlian dimulai dengan pendidikan formal yang selanjutnya melalui pengalaman dan praktik audit. Selain itu auditor harus menjalani pelatihan teknis yang cukup yang mencakup aspek teknis maupun pendidikan umum. Adanya pelatihan khusus bagi auditor bertujuan untuk meningkatkan mutu personal dan meningkatkan keahlian khusus di salah satu bidang untuk auditor menghasilkan kualitas audit yang baik. Kompetensi merupakan kualifikasi yang dibutuhkan oleh auditor untuk melaksanakan audit dengan benar dan juga bermanfaat untuk menjaga objektivitas dan integritas auditor. 6

Terkait kasus kegagalan audit muncul pertanyaan bagaimana kualitas audit yang dihasilkan, seberapa tinggi tingkat kompetensi dan independensi auditor saat ini, seberapa besar tingkat profesionalisme terhadap kualitas audit yang dihasilkan. Kualitas audit penting karena dengan kualitas audit yang tinggi maka akan dihasilkan laporan keuangan yang dapat dipercaya sebagai dasar pengambilan keputusan oleh pihak lain seperti investor. Selain itu adanya kekhawatiran akan merebaknya skandal keuangan dapat mengikis kepercayaan publik terhadap laporan keuangan dan profesi akuntan publik.

Tujuan dari audit laporan keuangan adalah memberikan pendapat atas kewajaran laporan keuangan yang dibuat oleh klien. Dalam memberikan pendapat auditor harus didukung dengan kecukupan bukti audit yang diperoleh selama proses audit. Dalam melaksanakan proses audit, auditor harus berpedoman pada standar profesional akuntan publik yang diterbitkan oleh Institut Akuntan Publik Indonesia (IAPI).

Gambaran mengenai pengelolaan dan tanggungjawab keuangan Negara di Provinsi Jawa Timur umumnya sudah baik. Data perolehan opini Badan Pemeriksa Keuangan (BPK) atas Laporan Keuangan Pemerintah Daerah (LKPD) Kabupaten/Kota se-Jawa Timur, menunjukkan jika perolehan opini Wajar Tanpa Pngecualian (WTP) mengalami peningkatan dari tahun ke tahun.

Gambar 1

Perolehan Opini LKDP

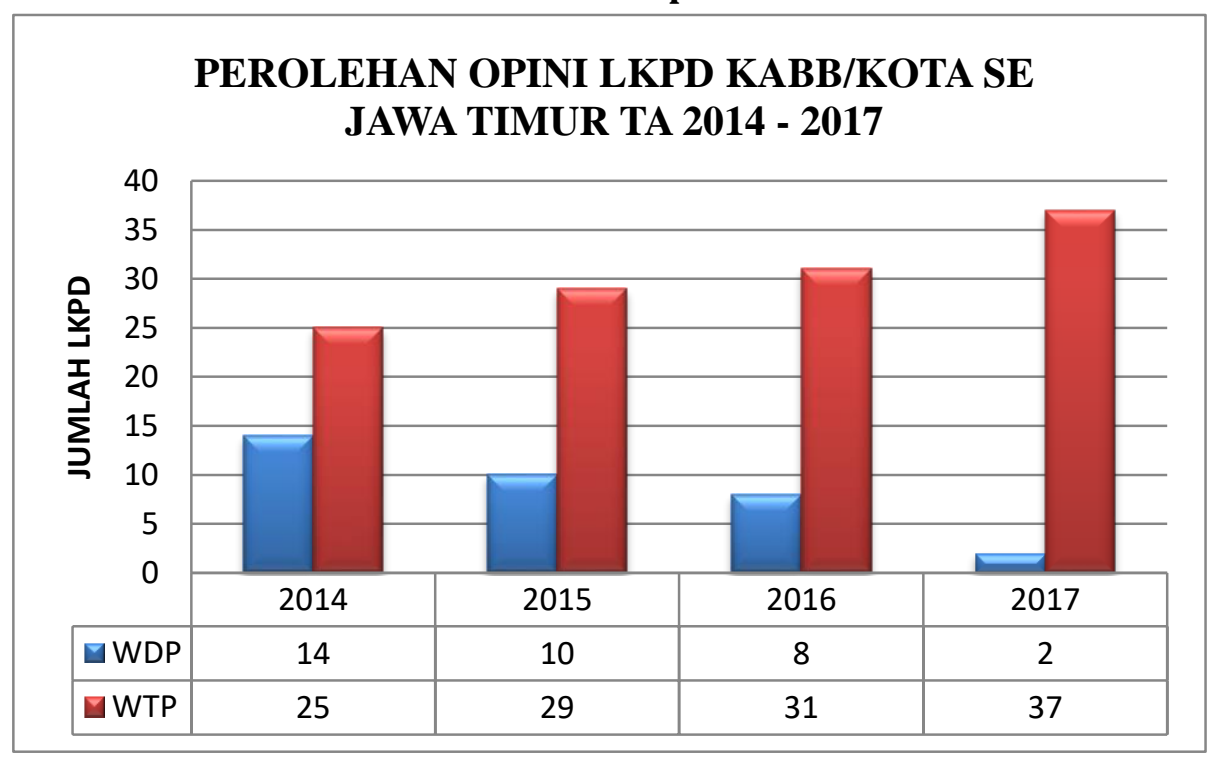

${ }^{6}$ Mulyadi, Auditing (Jakarta: PT. SalembaEmpat, 2002), hlm. 164. 128

Shafin: Sharia Finance and Accounting Journal

Vol.1 No.2 September 2021 
Dari grafik di atas, perolehan opini WTP menunjukkan tren yang meningkat. Sebaliknya, perolehan opini WDP menunjukkan tren penurunan dari tahun ke tahun. ${ }^{7}$ Pada tahun 2014 dari 39 Kabupaten terdapat 14 Kabupaten yang berstatus WDP dan 25 Kabupaten yang berstatus WTP. Pada tahun 2014 ini Kabupaten Sumenep masih berstatus WDP berdasarkan Laporan Hasil Pemeriksaan no. 75/LHP/XVII.SBY/05/2015. WDP diberikan kepada Pemkab Sumenep dikarenakan adanya salah saji material yang di temukan. Sedangkan Pada tahun 2014 ini Kabupaten Bangkalan belum konsisten dalam hal laporan keuangan dikarenakan dari status wajar tanpa pengecualian (WTP) berubah menjadi wajar dengan pengecualian (WDP) dikarenakan aset Negara yang disita Komisi Pemberantas Korupsi (KPK). Kabupaten Pamekasan pada tahun 2014 merupakan Kabupaten yang satu-satunya mendapatkan status WTP.

Pada tahun 2015 terdapat 29 Kabupaten yang berstatus WTP dan sisanya 10 Kabupaten yang berstatus WDP termasuk 3 kabupaten di Madura yakni Kabupaten Bangkalan, Kabupaten Sampang dan Kabupaten Sumenep. Pada tahun 2016 Kabupaten yang berstatus WDP hanya 8 Kabupaten diantaranya termasuk 3 Kabupaten di Madura.

Pada tahun 2017 hanya terdapat 2 Kabupaten yang berstatus WDP yaitu Kabupaten Sampang dan Kabupaten Lumajang. Pada tahun 2017 meningkat pesat peningkatan Kabupaten yang berstatus WTP termasuk Kabupaten Sumenep dan Kabupaten Bangkalan yang berganti status dari WDP menjadi WTP. Untuk Kabupaten Lumajang, pada tahun anggaran 2017 mengalami penurunan opini dibandingkan tahun-tahun sebelumnya. Sedangkan Kabupaten Sampang, belum berhasil untuk memperbaiki perolehan opini LKPD tahun sebelumnya.

Pada tahun anggaran 2017 Kabupaten Sumenep untuk pertama kalinya mendapatkan status WTP dari BPK atas hasil laporan Keuangannya yang terhindar dari adanya salah saji material. Dimana dalam 6 tahun terakhir Kabupaten Sumenep hanya berada di predikat wajar dengan pengecualian (WDP) dari Badan Pemeriksa Keuangan, opini yang diberikan kini berubah positif. Untuk pertama kalinya, keuangan Pemkab meraih opini wajar tanpa pengeculian (WTP). WTP di berikan atas hasil audit yang diterbitkan atas laporan keuangan, yang dianggap memberikan informasi yang bebas dari salah saji material. Dalam hal ini peneliti ingin meneliti lebih lanjut mengenai hasil audit yang dihasilkan oleh pemerintah sumenep. Berdasarkan uraian diatas, maka peneliti merencanakan mengadakan penelitian mengenai, "Pengaruh Profesionalisme, Independensi, dan Kompetensi Terhadap Kualitas Audit di Badan Pendapatan Pengelolaan Keuangan dan Aset Kabupaten Sumenep".

\section{METODE PENELITIAN}

Jenis penelitian yang digunakan adalah penelitian kausalitas yang bertujuan menjelaskan fenomena dalam bentuk pengaruh antar variabel, analisis berganda digunakan karena dalam penelitian ini jumlah variabel independennya lebih dari satu. Populasi dalam penelitian ini adalah semua auditor yang ada di Badan Pendapatan Pengelolaan Keuangan dan

\footnotetext{
7 BKN, “perolehan oponi LKDP”, LKDP, diakses dari http://www.dpr.go.id/dokakd/dokumen/BAKN-13 b8bff84bbea9634849ae1b25d29452a6.pdf, pada tanggal 7 September 2019 pukul 10.46.
} 
Aset Daerah Kabupaten Sumenep (BPPKAD). Populasi dalam penelitian ini adalah Pegawai Auditor yang ada di Badan Pendapatan Pengelolaan Keuangan dan Aset Daerah Kabupaten Sumenep (BPPKAD).

Pengambilan sampel yang digunakan dalam penelitian ini adalah pengambilan sampel jenuh. Teknik pengumpulan sampel ini semua anggota populasi digunakan sebagai sampel.Hal ini sering dilakukan bila jumlah populasi relative kecil atau penelitian yang ingin membuat generalisasi dengan kesalahan yang sangat kecil. berdasarkan teori diatas maka dalam penelitian ini semua jumlah populasi adalahsemua karyawan yang bertugas sebagai audit yang bekerja di BPPKAD Kabupaten Sumenep.

Ada dua jenis data yang digunakan dalam penelitian ini, yaitu data primer dan data sekunder. Data primer adalah data yang diperoleh atau dikumpulkan langsung di lapangan oleh orang yang melakukan penelitian atau yang bersangkutan yang memerlukannya. Data primer ini disebut juga data asli atau data baru. ${ }^{8}$ Dalam penelitian yang menjadi data primer adalah data yang berkaitan dengan auditor. Untuk memperoleh data tersebut peneliti melakukan penyebaran kuesioner yang telah disediakan oleh peneliti. Kuesioner tersebut di desain dengan menggunakan skala likert. Data sekunder adalah data yang diperoleh atau dikumpulkan oleh orang yang melakukan penelitian dari sumber-sumber yang telah ada. Data ini biasanya diperoleh dari perpustakaan atau dari laporan-laporan peneliti terdahulu. ${ }^{9}$ Untuk menunjang penelitian, penulis memperoleh data sekunder tersebut melalui buku kuliah dan buku umum yang relevan dengan permasalahan penelitian, penelitian terdahulu bisa berupa skripsi, tesis serta jurnal ilmiah yang dipublikasikan secara luas dan media publikasi yang menyediakan data yang berhubungan dengan permasalahan penelitian, serta internet yang menyediakan data mengenai objek penelitian serta jurnal yang berhubungan dengan permasalahan penelitian.

Dalam Penelitian ini metode pengumpulan data yang digunakan adalah Metode Angket (Kuesioner). Kuesioner adalah suatu teknik pengumpulan data yang dilakukan dengan cara memberi seperangkat pernyatan tertulis kepada responden untuk dijawabnya. Kuesioner yang digunakan peneliti sebagai instrumen penelitian, metode yang digunakan yaitu dengan menggunakan kuesioner tertutup.

Instrumen kuesioner harus diukur validitas dan reabilitas datanya sehingga penelitian tersebut menghasilkan data yang valid dan reliable. Instrumen yang digunakan untuk mengukur variabel penelitian dengan menggunakan skala likert. Skala likert adalah skala yang dapat digunakan untuk mengukur sikap, pendapat dan persepsi seseorang tentang sesuatu objek atau fenomena tertentu. ${ }^{10}$

Bentuk jawaban responden berupa pilihan dari lima alternatif yang ada, yaitu:

\footnotetext{
${ }^{8}$ Iqbal Hasan, Analisis data Penelitian dengan Statistik(Jakarta: PT. Bumi Aksara, 2004), hlm. 19.

${ }^{9}$ Iqbal Hasan, hlm., 19

${ }^{10}$ Syofian Siregar, Metode Penelitian Kuantitatif dilengkapi dengan perbandingan perhitungan manual \& SPSS(Bandung: Alfbeta 2007), hlm. 25.
} 
Tabel 1

Jawaban Responden

\begin{tabular}{|c|c|c|}
\hline Jawaban Responden & Keterangan & Nilai \\
\hline SS & Sangat Setuju & 5 \\
\hline S & Setuju & 4 \\
\hline N & Netral & 3 \\
\hline TS & Tidak Setuju & 2 \\
\hline STS & Sangat Tidak Setuju & 1 \\
\hline
\end{tabular}

Analisis data pertama menggunakan beberapa pengujian yaitu uji validitas untuk mengetahui kesahihan adalah menunjukkan sejauh mana suatu alat ukur mampu mengukur apa yang ingin di ukur. ${ }^{11}$ Analisis data kedua adalah dengan pengujian reabilitas yaitu untuk mengetahui sejauh mana hasil pengukuran tetap konsisten, apabila dilakukan pengukuran dua kali atau lebih terhadap gejala yang sama dengan menggunakan alat pengukur yang sama pula. ${ }^{12}$ Dimana pengujian reabilitas setiap variabel menggunakan tekhnik cronbach alpha. Suatu konstruk atau variabel dikatakan reliabel jika nilai CronbackAlpha $>0.60$. dan pengujian ketiga yaitu uji Asumsi Klasik yang terdiri dari uji normalitas untuk mengetahui apakah variabel dependen, independen atau keduanya berdistribusi normal, mendekati normal atau tidak. Uji Heteroskedastisitas untuk menguji apakah dalam model regresi linier terjadi ketidaksamaan varian dari residual satu pengamatan ke lainnya. Selanjutnya uji Multikolonieritas untuk mengetahui apakah model regresi masing-masing variabel bebas (independent) saling berhubungan secara linier. Uji Hipotesis dalam penelitian ini sendiri melalui analisis regresi linier berganda dan uji koefisien determinasi $\left(\mathrm{R}^{2}\right)$.

\section{HASIL DAN PEMBAHASAN}

Deskripsi data responden menggambarkan keadaan atau kondisi responden yang merupakan informasi tambahan untuk memahami hasil-hasil penelitian. Responden dalam penelitian ini memiliki beberapa karakteristik. Berikut ini karakteristik responden diantaranya yaitu:

\section{a. Profil Responden}

1) Usia

Karakteristik responden berdasarkan usia dapat dilihat pada Tabel 2 sebagai berikut:

Tabel 2

Karakteristik Responden Berdasarkan Usia

\begin{tabular}{|c|c|c|}
\hline No & Usia & Jumlah \\
\hline 1 & $20-29$ & 3 \\
\hline 2 & $30-39$ & 10 \\
\hline 3 & $\geq 40$ & 17 \\
\hline & Jumlah & 30 \\
\hline
\end{tabular}

Sumber: Data olah primer (2020)

\footnotetext{
${ }^{11}$ Syofian Siregar, Metode Penelitian Kuantitatif, Edisi Pertama, Cetakan ke-2, (Jakarta: kencana, 2013), hlm 46.

${ }^{12}$ Syofian Siregar, hlm., 43.
}

Shafin: Sharia Finance and Accounting Journal

Vol. 1 No. 2 September 2021 
Tabel diatas menunjukkan bahawa karakteristik responden berdasarkan usia yaitu pegawai yang berusia 20-29 tahun sebanyak 3 pegawai, kemudian usia 30-39 tahun sebanyak 10 pegawai dan usia $\geq 40$ tahun sebanyak 17 pegawai dengan presentase. Hasilini menunjukkan bahwa sebagian besar pegawai BPPKAD Sumenep dalam penelitian ini adalah berusia 30 - 39 tahun.

\section{2) Jenis kelamin}

Karakteristik responden berdasarkan usia dapat dilihat pada tabel 3 sebagai berikut:

Tabel 3

Karakteristik Responden Berdasarkan Jenis Kelamin

\begin{tabular}{|c|c|c|}
\hline No & Jenis Kelamin & Jumlah \\
\hline 1 & Laki - Laki & 23 \\
\hline 2 & Perempuan & 7 \\
\hline & Jumlah & 30 \\
\hline
\end{tabular}

Sumber: Data olah primer (2020)

Tabel diatas menunjukkan bahwa karakteristik responden berdasarkan jenis kelamin yaitu sebanyak 23 pegawai laki-laki dan sebanyak 7 pegawai perempuan yang menjadi responden dalam penelitian ini. Hasil menunjukkan sebagian besar karyawan BPPKAD Sumenep dalam penelitian ini adalah laki - laki.

\section{3) Pendidikan Terakhir}

Karakteristik responden berdasarkan usia dapat dilihat pada Tabel 4. sebagai berikut:

Tabel 4

Karakteristik Responden Berdasarkan Pendidikan Terakhir

\begin{tabular}{|c|c|c|}
\hline No & Pendidikan Terakhir & Jumlah \\
\hline 1 & SMA & - \\
\hline 2 & D3 & 17 \\
\hline 3 & S1 & 13 \\
\hline 4 & S2 & 30 \\
\hline
\end{tabular}

Sumber: Data olah primer (2020)

Tabel di atas menunjukkan bahwa karakteristik responden pegawai lulusan S1 sebanyak 17 orang pegawai dan 13 pegawai lulusan S2. Sedangakan lulusan SMA dab D3 tidak ada. Hal ini berarti menunjukkan bahwa sebagian besar pegawai BPPKAD Sumenep adalah lulusan S2.

\section{b. Uji Kualitas Data}

Pada tahap ini, kualitas data yang dihasilkan dari penggunaan instrumen penelitian dapat dievaluasi melalui uji validitas dan realibilitas. Tujuan dari pengujian ini adalah untuk mengetahui apakah setiap pertanyaan yang digunakan dalam penelitian ini layak atau tidak untuk dipakai. 


\section{1) Uji Validitas}

Uji validitas bertujuan untuk mengukur valid atau tidak suatu kuesioner atau dengan kata lain apakah kuesioner tersebut mampu mengungkapkan suatu variabel yang seharusnya diukur dari person correlation. Hal ini dapat dilakukan dengan uji signifikansi yaitu dengan membandingkan nilai $r_{\text {tabel }}$ dengan $r_{\text {hitung }}$ untuk degree of freedom $(\mathrm{df})=\mathrm{n}-2$, dimana $\mathrm{n}$ adalah jumlah sampel dan alpha $(\alpha=5 \%)$. apabila $r_{\text {hitung }}$ lebih besar dari pada $r_{\text {tabel }}$ dan nilai $r$ positif, maka butir pertanyaan tersebut dapat dikatakan valid, begitupun sebaliknya.

Pada penelitian ini besarnya $\mathrm{df}$ adalah $30-2$ atau $\mathrm{df}=28$ dan alpha $0,05(\alpha=5 \%)$ sehingga didapat $r_{\text {tabel }} 0,361$. Selanjutnya berdasarkan hasil perhitungan data penelitian menggunakan program SPSS, diperoleh nilai $r_{\text {hitung }}>r_{\text {tabel. }}$. Hasil analisisnya dapat dilihat pada tabel berikut:

Tabel 5

Hasil Uji Validitas Tiap Item Pertanyaan

Variabel Profesionalisme (X1), Variabel Independensi (X2), Variabel Kompetensi (X3) dan Kualitas Audit (Y) ${ }^{13}$

\begin{tabular}{|c|c|c|c|}
\hline Item & $\mathbf{r}_{\text {hitung }}$ & $\mathbf{r}_{\text {tabel }}$ & validitas \\
\hline \multicolumn{4}{|c|}{ Variabel Profesionalisme (X1) } \\
\hline $\mathrm{X} 1.1$ & 0.755 & 0,361 & Valid \\
\hline $\mathrm{X} 1.2$ & 0,753 & 0,361 & Valid \\
\hline $\mathrm{X} 1.3$ & 0,609 & 0,361 & Valid \\
\hline $\mathrm{X} 1.4$ & 0,864 & 0,361 & Valid \\
\hline $\mathrm{X} 1.5$ & 0,586 & 0,361 & Valid \\
\hline $\mathrm{X} 1.6$ & 0,653 & 0,361 & Valid \\
\hline $\mathrm{X} 1.7$ & 0,385 & 0,361 & Valid \\
\hline \multicolumn{4}{|c|}{ Variabel Indepedensi (X2) } \\
\hline $\mathrm{X} 2.1$ & 0,806 & 0,361 & Valid \\
\hline $\mathrm{X} 2.2$ & 0,766 & 0,361 & Valid \\
\hline $\mathrm{X} 2.3$ & 0,900 & 0,361 & Valid \\
\hline $\mathrm{X} 2.4$ & 0,692 & 0,361 & Valid \\
\hline $\mathrm{X} 2.5$ & 0,688 & 0,361 & Valid \\
\hline \multicolumn{4}{|c|}{ Variabel Kompetensi (X3) } \\
\hline $\mathrm{X} 3.1$ & 0,888 & 0,361 & Valid \\
\hline
\end{tabular}

\footnotetext{
${ }^{13}$ Sumber data diolah dari SPSS 20, tahun 2019
}

Shafin: Sharia Finance and Accounting Journal

Vol. 1 No. 2 September 2021 
Khoirun Nisa Imami, Farahdilla Kutsiyah, Ira Hasti Priyadi

\begin{tabular}{|c|l|l|l|}
\hline X3.2 & 0,728 & 0,361 & Valid \\
\hline X3.3 & 0,902 & 0,361 & Valid \\
\hline X3.4 & 0,821 & 0,361 & Valid \\
\hline \multicolumn{4}{|c|}{ Variabel Kualitas Audit (Y) } \\
\hline Y1 & 0,627 & 0,361 & Valid \\
\hline Y2 & 0,901 & 0,361 & Valid \\
\hline Y3 & 0,860 & 0,361 & Valid \\
\hline Y4 & 0,732 & 0,361 & Valid \\
\hline Y5 & 0,760 & 0,361 & Valid \\
\hline Y6 & 0,769 & 0,361 & Valid \\
\hline
\end{tabular}

\section{2) Uji Reliabilitas}

Uji reliabilitas bertujuan untuk mengetahui konsistensi jawaban responden atau kuesioner yang diberikan. Apabila nilai cronbach's alpha $(\alpha)$ suatu variabel $\geq 0,60$ maka indikator yang digunakan oleh variabel terikat tersebut reliabel, jika nilai cronbach's alpha $(\alpha)$ suatu variabel $<0,60$ maka indikator yang digunakan oleh variabel tersebut tidak reliabel.

Tabel 6

Hasil Uji Reliabilitas Tiap Item Pertanyaan'14

\begin{tabular}{|c|c|c|}
\hline Variabel & Nilai cronbach's alpha & Keterangan \\
\hline Profesionalisme (X1) & 0,757 & Reliabel \\
\hline Independensi (X2) & 0,814 & Reliabel \\
\hline Kompetensi (X3) & 0,856 & Reliabel \\
\hline Kualitas Audit (Y) & 0,856 & Reliabel \\
\hline
\end{tabular}

Dari keterangan tabel diatas dapat diketahui bahwa masing-masing variabel memiliki cronbach's alpha > 0,60. Dengan demikian variabel Profesionalisme, Independensi, Kompetensi dan Kualitas audit dapat dikatakan reliabel.

\footnotetext{
${ }^{14}$ Sumber data diolah dari SPSS 20, tahun 2019 134

Shafin: Sharia Finance and Accounting Journal

Vol.1 No.2 September 2021
} 


\section{c. Uji Asumsi Klasik}

\section{1) Uji Multikolinieritas}

2) uji multolinieritas bertujuan untuk menguji apakah model regresi ditemukan korelasi antar variabel bebas (independen). Model regresi yang baik seharusnya tidak terjadi korelasi diantara variabel bebas.

Salah satu cara yang dipakai untuk mendeteksi ada tidaknya gejala multikolinieritas adalah melihat nilai tolerance dan lawannya serta nilai VIF (Varian Inflation Factor). Jika nilai tolerance lebih besar dari 0.10 dan nilai VIF lebih kecil dari 10, maka tidak terjadi multikolineritas. Hasil uji multikolinieritas tiap variabel, yaitu:

\section{Tabel 7}

Uji Multikolinieritas ${ }^{15}$

\section{Coefficients ${ }^{\mathrm{a}}$}

\begin{tabular}{|c|c|c|c|c|c|c|c|c|}
\hline \multirow{2}{*}{\multicolumn{2}{|c|}{ Model }} & \multicolumn{2}{|c|}{$\begin{array}{l}\text { Unstandardiz } \\
\text { ed } \\
\text { Coefficients }\end{array}$} & \multirow{2}{*}{$\begin{array}{c}\begin{array}{c}\text { Standardiz } \\
\text { ed } \\
\text { Coefficient } \\
\text { s }\end{array} \\
\text { Beta }\end{array}$} & \multirow[t]{2}{*}{$\mathrm{t}$} & \multirow[t]{2}{*}{ Sig. } & \multicolumn{2}{|c|}{$\begin{array}{l}\text { Collinearity } \\
\text { Statistics }\end{array}$} \\
\hline & & B & $\begin{array}{l}\text { Std. } \\
\text { Error }\end{array}$ & & & & $\begin{array}{l}\text { Toler } \\
\text { ance }\end{array}$ & VIF \\
\hline \multirow{4}{*}{1} & (Constant) & $\begin{array}{r}6,30 \\
8\end{array}$ & 3,963 & & 1,591 & 124 & & \\
\hline & $\begin{array}{l}\text { PROFESIONALIS } \\
\text { ME }\end{array}$ & , 193 & ,337 &,- 226 &,- 573 & ,572 & 113 & 8,885 \\
\hline & INDEPENDENSI & ,909 & ,435 & 830 & 2,088 & , 047 & ,111 & 9,007 \\
\hline & KOMPETENSI & 331 & 157 & 287 & 2,116 & 044 & ,953 & 1,049 \\
\hline
\end{tabular}

a. Dependent Variable: KUALITAS AUDIT

Tabel diatas menunjukkan bahwa nilai tolerance variabel profesionalisme (X1) sebesar $0,113>0,10$, indepedensi (X2) sebesar 0,111 >0,10 dan kompetensi (X3) sebesar 0,953>0,10 serta nilai VIF masing-masing VIF yaitu 8,885 < 10, 9,007 < 10 dan 1,049 $<10$ sehingga dapat disimpulkan bahwa antar variabel bebas tidak terjadi multikolinieritas.

\section{3) Uji Normalitas}

Uji normalitas bertujuan untuk mengetahui apakah variabel dependen, independen atas keduanya berdistribusi normal, mendekati normal atau tidak. Model regresi yang baik hendaknya berdistribusi normal atau mendekati normal. Pengujian normalitas dalam penelitian ini menggunakan grafik normal probability plot. Hasil uji normalitas dengan menggunakan grafik normal probability plot, yaitu:

\footnotetext{
${ }^{15}$ Sumber data diolah dari SPSS 20, tahun 2019
} 


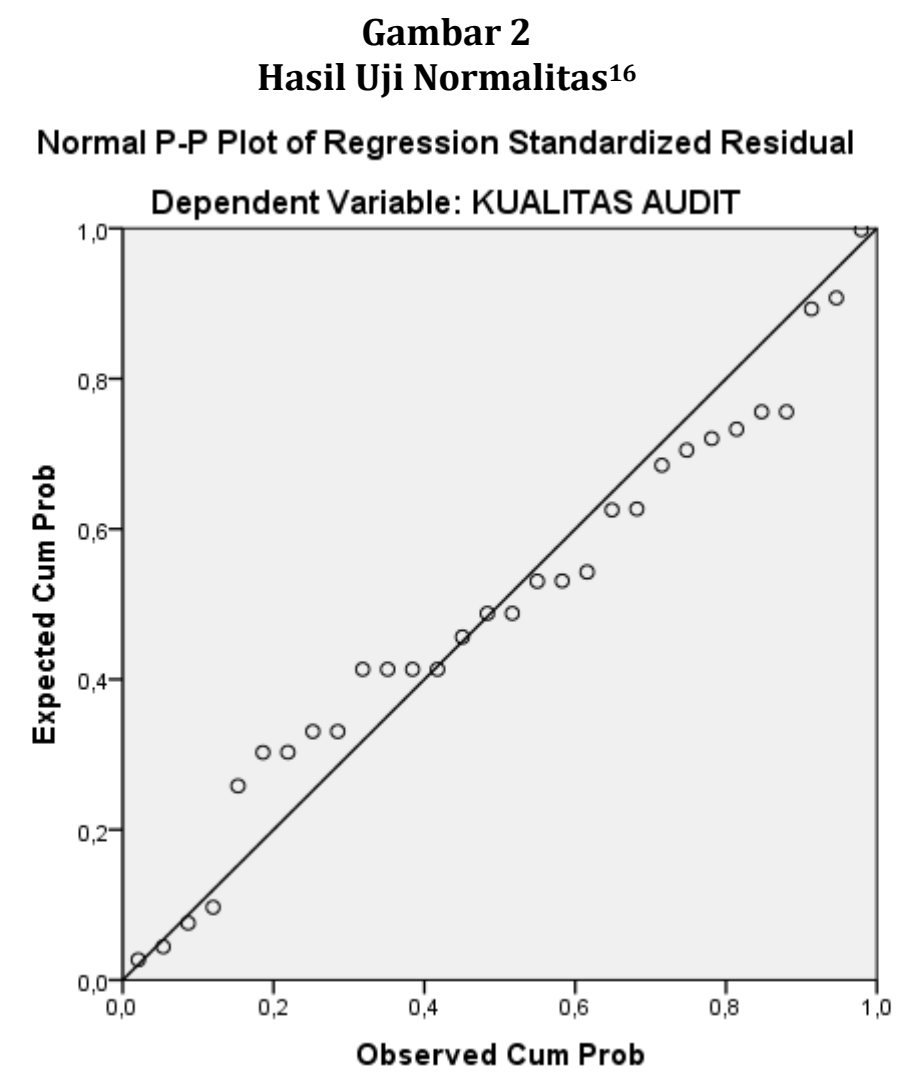

Dari hasil output SPSS di atas, pada grafik normal probability plot menunjukkan bahwa data (titik-titik) menyebar di sekitar garis diagonal dan mengikuti arah garis diagonal, maka dapat disimpulkan model regresi memenuhi asumsi normalitas.

Pada uji normalitas, jika hanya melihat hasil output grafik normal probability plot, ada kemungkinan subjektivitas dalam menginterpretasikan hasil grafik tersebut. Oleh karena itu, untuk lebih memastikan bahwa model regresi memenuhi asumsi normalitas, maka dalam penelitian ini juga dilakukan One Sample Kolmogorov-Smirnov. Berikut hasil uji One Sample Kolmogorov-Smirnov penelitian ini:

\footnotetext{
${ }^{16}$ Sumber data diolah dari SPSS 20, tahun 2019 136

Shafin: Sharia Finance and Accounting Journal

Vol.1 No.2 September 2021
} 


\section{Tabel 8}

Hasil Uji Kolmogorov-Smirnov ${ }^{17}$

One-Sample Kolmogorov-Smirnov Test

\begin{tabular}{|ll|r|}
\hline & & $\begin{array}{r}\text { Unstanda } \\
\text { rdized Residual }\end{array}$ \\
\hline $\mathrm{N}$ & Mean & 30 \\
Normal Parametersa,b & $0 \mathrm{E}-7$ \\
& Std. & 1,668030 \\
& Deviation & 05 \\
Most Extreme & Absolute &, 132 \\
Differences & Positive &, 132 \\
& Negative &,- 126 \\
Kolmogorov-Smirnov Z & &, 723 \\
Asymp. Sig. (2-tailed) & &, 672 \\
\hline
\end{tabular}

a. Test distribution is Normal.

b. Calculated from data.

Berdasarkan hasil uji normalitas, diperoleh nilai signifikansi 0,672 lebih besar dari 0,05 , sehingga dapaat disimpulkan bahwa data berdistribusi normal.

\section{4) Uji heterokedastisitas}

Uji heterokedastisitas untuk mengujiapakah dalam model regresi terjadi ketidaksamaan variance dari residual satu pengamatan ke pengamatan yang lain. Dalam penelitian ini, untuk mendeteksi ada tidaknya gejala heterokedastisitas salah satunya dengan menggunakan uji grafik plotyang dihasilkan dari pengolahan data dengan menggunakan program SPSS 20 yang dapat dilihat pada Gambar di bawah ini:

\footnotetext{
${ }^{17}$ Sumber data diolah dari SPSS 20, tahun 2019
}

Shafin: Sharia Finance and Accounting Journal

Vol. 1 No. 2 September 2021 


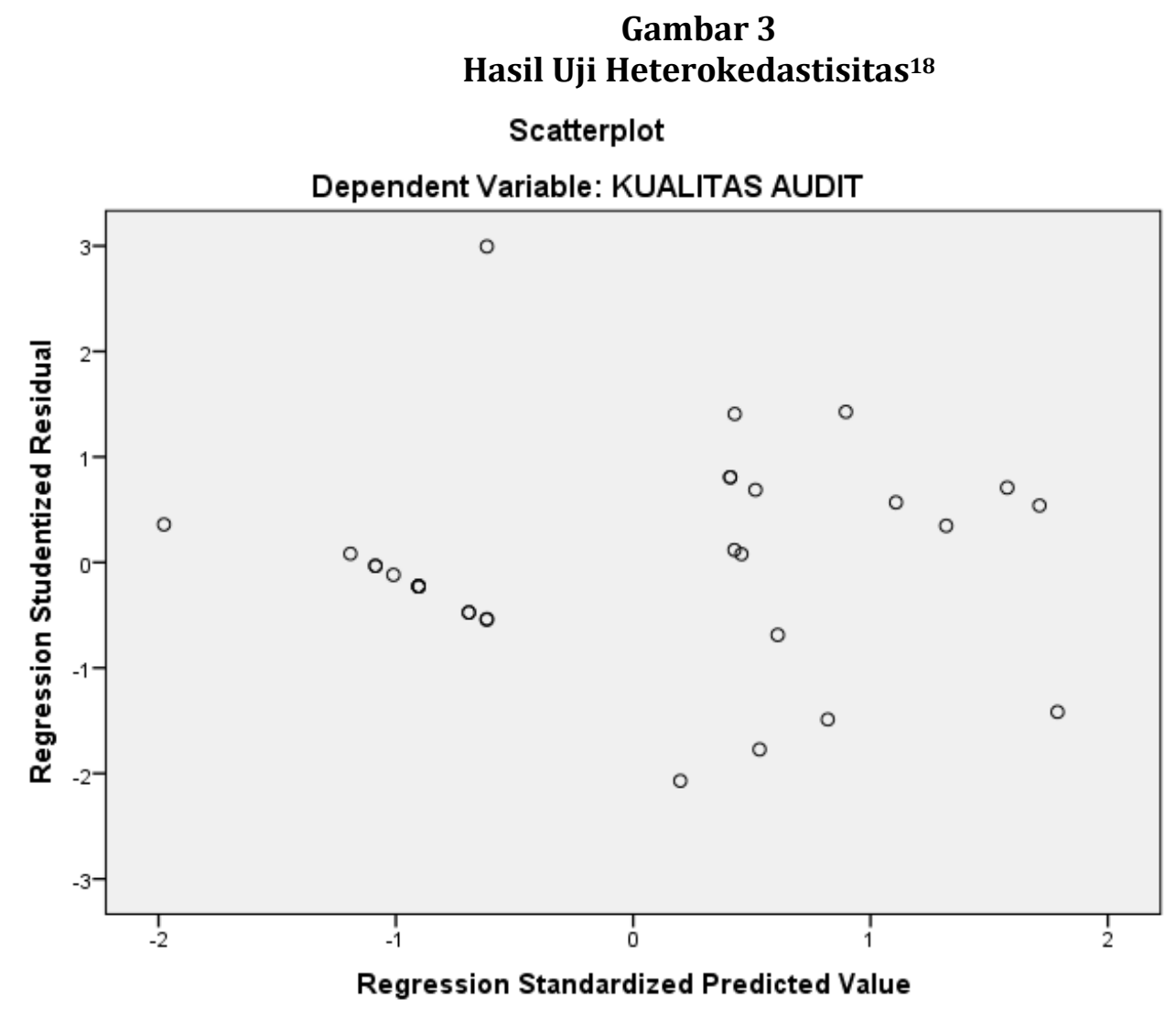

Dari grafik scatterplot memperlihatkan bahwa tititk - tititk pada grafik tidak bisa membentuk pola tertentu yang jelas, dimana titik - titik menyebar diatas dan dibawah angka 0 pada sumbu $Y$, sehingga grafik tersebut tidak bisa dibaca dengan jelas. Hasil ini memperlihatkan bahwa tidak terjadi herokedastisitas.

\section{a. Pembuktian Hipotesis}

\section{1) Uji Analisis Regresi Linier Berganda}

Pembuktian hipotesis dilakukan dengan melakukan analisis regresi linier berganda. Analisis regresi linier berganda digunakan bila jumlah variabel bebas (independent) lebih dari satu dan satu variabel tak bebas (dependent). Persamaan umum regresi linier berganda adalah sebagai berikut:

$\mathrm{Y}=\mathrm{a}+\mathrm{b}_{1} \mathrm{X}_{1}+\mathrm{b}_{2} \mathrm{X}_{2}+\mathrm{b}_{3} \mathrm{X}_{3}+\mathrm{e}$

Dari hasil analisis menggunakan program SPSS versi 20 for windows diperoleh hasil sebagai berikut:

\footnotetext{
${ }^{18}$ Sumber data diolah dari SPSS 20, tahun 2019 138

Shafin: Sharia Finance and Accounting Journal

Vol.1 No.2 September 2021
} 
Tabel 9

Hasil Analisis Regresi Linier Berganda ${ }^{19}$

Coefficients ${ }^{\mathrm{a}}$

\begin{tabular}{|c|c|c|c|c|c|c|c|c|}
\hline \multirow{2}{*}{\multicolumn{2}{|c|}{ Model }} & \multicolumn{2}{|c|}{$\begin{array}{l}\text { Unstandardiz } \\
\text { ed } \\
\text { Coefficients }\end{array}$} & \multirow{2}{*}{$\begin{array}{c}\text { Standardiz } \\
\text { ed } \\
\text { Coefficient } \\
\text { s } \\
\text { Beta }\end{array}$} & \multirow[t]{2}{*}{$\mathrm{t}$} & \multirow[t]{2}{*}{ Sig. } & \multicolumn{2}{|c|}{$\begin{array}{c}\text { Collinearity } \\
\text { Statistics }\end{array}$} \\
\hline & & B & $\begin{array}{l}\text { Std. } \\
\text { Error }\end{array}$ & & & & $\begin{array}{l}\text { Toler } \\
\text { ance }\end{array}$ & VIF \\
\hline \multirow{4}{*}{1} & (Constant) & $\begin{array}{r}6,30 \\
8\end{array}$ & 3,963 & & 1,591 & ,124 & & \\
\hline & $\begin{array}{l}\text { PROFESIONALIS } \\
\text { ME }\end{array}$ & 193 & 337 &,- 226 &,- 573 & ,572 & 113 & 8,885 \\
\hline & INDEPENDENSI & ,909 & ,435 & ,830 & 2,088 & ,047 & 111 & 9,007 \\
\hline & KOMPETENSI & ,331 & 157 & 287 & 2,116 & 044 & 953 & 1,049 \\
\hline
\end{tabular}

a. Dependent Variable: KUALITAS AUDIT

Berdasarkan hasil analisis regresi linier sederhana pada tabel tersebut diperoleh koefisien variabel Profesionalisme $(X 1)=-0,193$, variabel Independensi $(X 2)=0,909$ dan Kompetensi $(X 3)=0,331$ serta konstanta sebesar $=6,308$ sehingga model persamaan regresi yang diperoleh dalam penelitian ini adalah sebagi berikut:

$\mathrm{Y}=6,308+-0,193 \mathrm{X}_{1}+0,909 \mathrm{X}_{2}+0,331 \mathrm{X}_{3}+3,963$

Model persamaan regresi linier berganda tersebut ditafsirkan sebagai berikut:

a. $a=(6,308)$ artinya variabel independen mempunyai pengaruh positif terhadap kualitas audit. Nilai konstanta kualitas audit sebesar $(6,308)$ menunjukkan bahwa semakin besar profesionalisme, independensi dan kompetensi auditor, maka semakin besar pengaruhnya terhadap kualitas audit.

b. $b_{1}=(-0,193)$, Nilai koefisien regresi variabel profesionalisme sebesar $(-0,193)$ berarti jika variabel independen lain nilainya tetap dan profesionalismemengalami kenaikkan 1\%, maka kualitas audit akan mengalami penurunan sebesar 0,913.Koefisien bernilai negatif artinya terjadi hubungan negatif antara profesionalisme dengan kualitas audit, semakin naik profesionalisme maka semakin turun kualitas audit.

c. $b_{2}=(0.909)$, Nilai koefisien regresi variabel Independensisebesar $(0,909)$ berarti jika variabel independen lain nilainya tetap dan Independensi mengalami kenaikkan 1\% maka kualitas audit akan mengalami peningkatan sebesar 0,909. Koefisien bernilai positif artinya terjadi hubungan positif antara independensi dan kualitas audit, semakin naik independensi maka semakin meningkat kualitas audit.

d. $b_{3}=(0,331)$, nilai koefisien regresi variabel kompetensi sebesar $(0,331)$ berarti jika variabel kompetensi lain nilainya tetap dan kompetensi mengalami kenaikkan 1\% maka kualitas audit akan mengalami peningkatan sebesar 0,331. Koefisien bernilai positif artinya terjadi hubungan positif antara kompetensi dan kualitas audit, semakin naik kompetensi maka semakin meningkat kualitas audit.

e. Standar error sebesar 3,963 artinya seluruh variabel yang dihitung dalam uji SPSS memiliki tingkat variabel pengganggu sebesar 2,963.

\footnotetext{
${ }^{19}$ Sumber data diolah dari SPSS 20, tahun 2019
} 


\section{2) Uji Signifikan Simultan/ Uji Serentak (uji F)}

Uji F dilakukan untuk memgetahui sejauh mana pengaruh secara simultan (bersamasama) antara variabel bebas terhadap variabel dependen, dengan $\alpha=0,05$.

Uji F dikatakan berpengaruh apabila ada salah satu atau beberapa variabel independen atau semua variabel independen berpengaruh terhadap variabel dependen. Dengan menggunakan nilai probabilitas $0,05(\alpha=5 \%)$, dimana jika nilai $\alpha>\operatorname{sig}$ atau nilai sig $<\alpha$ maka dapat diputuskan uji F berpengaruh.

Berikut hasil uji signifikan secara simultan variabel independen:

Tabel 10

Hasil Analisis Uji F

ANOVA $^{\mathrm{a}}$

\begin{tabular}{|rl|r|r|r|c|c|}
\hline \multicolumn{1}{|l|}{ Model } & \multicolumn{1}{|c|}{ Sum of } & Df & Mean Square & F & Sig. \\
& & Squares & & & & \\
\hline \multirow{2}{*}{1} & Regression & 96,279 & 3 & 32,093 & 10,341 &, $000^{\mathrm{b}}$ \\
& Residual & 80,687 & 26 & 3,103 & & \\
& Total & 176,967 & 29 & & & \\
\hline
\end{tabular}

a. Dependent Variable: KUALITAS AUDIT

b. Predictors: (Constant), KOMPETENSI, PROFESIONALISME, INDEPENDENSI

Hasil uji $\mathrm{F}$ tersebut di peroleh nilai $\mathrm{F}_{\text {hitung }}$ sebesar 10,341 dengan tingkat signifikan $0,000<0,05$, sehingga keputusannya adalah variabel X (profesionalisme,Independensi dan kompetensi) berpengaruh secara simultan terhadap kualitas audit pada BPPKAD Sumenep.

\section{3) Uji Signifikan Individual (uji t)}

Uji statistik t pada dasarnya menunjukkan seberapa jauh pengaruh satu variabel penjelas secara individual dalam menerangkan variasi variabel terikat. Untuk mengetahui apakah variabel independen mempunyai pengaruh secara parsial terhadap variabel dependen maka digunakan nilai probabilitas 0,05 ( $\alpha=5 \%$ ), dimana jika nilai $\alpha>$ sig atau sig $\langle\alpha$ maka variabel independen mempunyai pengaruh secara parsial terhadap variabel dependen.

Berikut uji t dengan menggunakan SPSS versi 20: 
Tabel 11

Hasil Analisis Uji t ${ }^{20}$

Coefficients ${ }^{a}$

\begin{tabular}{|c|c|c|c|c|c|c|}
\hline \multicolumn{2}{|c|}{ Model } & \multicolumn{2}{|c|}{$\begin{array}{l}\text { Unstandardized } \\
\text { Coefficients }\end{array}$} & \multirow{2}{*}{$\begin{array}{c}\begin{array}{c}\text { Standardize } \\
\text { d } \\
\text { Coefficients }\end{array} \\
\text { Beta }\end{array}$} & \multirow[t]{2}{*}{$\mathrm{T}$} & \multirow[t]{2}{*}{ Sig. } \\
\hline & & B & Std. Error & & & \\
\hline \multirow{4}{*}{1} & (Constant) & 6,308 & 3,963 & & 1,591 & 124 \\
\hline & $\begin{array}{l}\text { PROFESIONALISM } \\
\text { E }\end{array}$ &,- 193 & ,337 &,- 226 &,- 573 & ,572 \\
\hline & INDEPENDENSI & ,909 & , 435 & ,830 & 2,088 & 047 \\
\hline & KOMPETENSI & 331 & 157 & 287 & 2,116 & ,044 \\
\hline
\end{tabular}

a. Dependent Variable: KUALITAS AUDIT

Berdasarkan hasil data pengujian melalui SPSS, pengaruh masing -masing variabel dapat dijelaskan sebagai berikut:

a. Variabel profesionalisme $\left(\mathrm{X}_{1}\right)$ diperoleh $\mathrm{t}_{\text {hitung }}$ sebesar - 0,573 dengan taraf sig 0,572. Hasil uji tersebut menunjukkan bahwa nilai signifikan0,572 $>0,05$ dan nilai $t_{\text {hitung }}-0,573<t_{\text {tabel }}$ 2,052 dengan demikian, dapat disimpulkan bahwa variabel profesionalisme secara parsial tidak berpengaruh terhadap kualitas audit pada Badan Pendapatan Pengelolaan dan Aset Keuangan Daerah Sumenep (BPPKAD).

b. Variabel indepedensi $\left(\mathrm{X}_{2}\right)$ diperoleh $\mathrm{t}_{\text {hitung }}$ sebesar 2,088 dengan taraf sig 0,047. Hasil uji tersebut menunjukkan bahwa nilai signifikan 0,047 $<0,05$ dan nilai $t_{\text {hitung }} 2,088>t_{\text {tabel }} 2,052$ dengan demikian, dapat disimpulkan bahwa variabel independensi secara parsial berpengaruh terhadap kualitas audit secara parsial berpengaruh terhadap kinerja karyawan pada BPPKAD Sumenep.

c. Variabel kompetensi $\left(\mathrm{X}_{3}\right)$ diperoleh $\mathrm{t}_{\text {hitung }}$ sebesar 2,116 dengan taraf sig 0,044. Hasil uji tersebut menunjukkan bahwa nilai signifikan 0,044<0,05 dan nilai $t_{\text {hitung }} 2,116>t_{\text {tabel }} 2,052$ dengan demikian, dapat disimpulkan bahwa variabel kompetensi secara parsial berpengaruh terhadap kinerja karyawan pada BPPKAD Sumenep.

\section{4) Koefisien Determinasi $\left(R^{2}\right)$}

Koefisien determinasi $\left(\mathrm{R}^{2}\right)$ digunakan untuk mengukur seberapa besar pengaruh variabel - variabel bebas terhadap variabel terikat. Koefisien determinasi menunjukkan besarnya kontribusi variabel bebas (X) terhadap variabel terikat (Y). Semakin besar nilai koefisien determinasi, maka semakin baik pula kemampuan variabel terikat $(\mathrm{Y})$ dengan melihat R Square. Berdasarkan pengujian dengan menggunakan program SPSS seperti tabel di bawah ini menghasilkan.

\footnotetext{
${ }^{20}$ Sumber data diolah dari Output SPSS 20, tahun 2019
}

Shafin: Sharia Finance and Accounting Journal

Vol. 1 No. 2 September 2021 
Tabel 12

Hasil Koefisien Determinasi $\mathbf{R}^{2}$

Model Summary

\begin{tabular}{|l|r|r|r|r|}
\hline Model & \multicolumn{1}{|c|}{$\mathrm{R}$} & \multicolumn{1}{|c|}{ R Square } & \multicolumn{1}{|c|}{$\begin{array}{c}\text { Adjusted R } \\
\text { Square }\end{array}$} & $\begin{array}{l}\text { Std. Error of the } \\
\text { Estimate }\end{array}$ \\
\hline 1 &, $738^{\mathrm{a}}$ &, 544 &, 491 & 1,762 \\
\hline
\end{tabular}

a. Predictors: (Constant), KOMPETENSI, PROFESIONALISME, INDEPENDENSI

Sumber: Output SPSS 20, tahun 2019

Hasil analisis data tersebut terlihat bahwa besarnya Rsquare adalah 0, 544 atau 54,4\% kemampuan model regresi pada penelitian ini dalam menerangkan variabel dependen. Artinya $54,4 \%$ kualitas audit dijelaskan oleh variasi variabel independen profesionalisme, independensi, kompetensi. Sedangkan sisanya $(100 \%-54,4 \%=45,6 \%)$ dipengaruhi oleh variabel - variabel lainnya yang tidak diperhitungkan dalam analisis penelitian ini.

\section{A. Pembahasan}

\section{Profesionalisme indepedensi dan kompetensi yang mempengaruhi kualias audit.}

\begin{tabular}{|c|c|c|c|c|c|}
\hline Variabel & $\begin{array}{c}\text { Koefisien } \\
\text { regresi }\end{array}$ & t-statistik & Adj R square & $\begin{array}{c}\text { F- } \\
\text { hitung }\end{array}$ & VIF \\
\hline Konstanta & 6,308 & 1,591 & 0,491 & $10,341^{* *}$ & \\
\hline profesionalisme & $-1,93$ & $-0,573^{* *}$ & & & 8,885 \\
\hline Independensi & 0,909 & $2,088^{* *}$ & & & 9,007 \\
\hline Kompetensi & 0,331 & $2,116^{* *}$ & & & 1,049 \\
\hline
\end{tabular}

Keterangan:

Dependen variabel: kualitas audit

$\left.{ }^{* * *}\right)$. Nyata pada taraf kesalahan $(\alpha) 1 \%$

**). Nyata pada taraf kesalahan $(\alpha) 5 \%$

*). Nyata pada taraf kesalahan $(\alpha) 10 \%$

t-tabel: $\mathrm{t}_{(\alpha, \mathrm{df})}: \mathrm{t}_{(0,10,27)}=1,703 ; \mathrm{t}_{(0,05,27)}=2,052 ; \mathrm{t}_{(0,01,27)}=2,770$

F -tabel: $F \alpha(k, n-k): F_{0,10}(3,27)=2,51 ; F_{0,05}(3,27)=3,35 ; F_{0,01}(3,27)=5,49$

\section{a. Pengaruh profesionalisme terhadap kualitas audit}

Pembahasan ini untuk menjawab dan menjelaskan tentang rumusan masalah, yaitu untuk mengetahui pengaruh profesionalisme terhadap kualitas audit di Badan Pendapatan Pengelolaan Keuangan dan Aset Daerah Kabupaten Sumenep. Maka dapat dijelaskan melalui poin pembahasan berikut ini:

Menurut Yendrawati Profesionalisme adalah konsep untuk mengukur bagaimana para profesional memandang profesi mereka yang tercermin dalam sikap dan perilaku mereka. 
Profesionalisme juga merupakan sikap bertanggung jawab terhadap apa yang telah ditugaskan kepadanya. ${ }^{21}$

Selanjutnya berdasarkan hasil analisis uji t (secara parsial) diketahui variabel profesionalisme $\left(\mathrm{X}_{1}\right)$ di peroleh $t_{\text {hitung }}$ sebesar $-0,573$ dengan taraf signifikan 0,572. Hasil uji tersebut menunjukkan bahwa nilai signifikan 0,572 $>0,05$ dan nilai $t_{\text {hitung }}-0,573<t_{\text {tabel }} 2,052$ maka dapat disimpulkan bahwa variabel profesionalisme secara parsial tidak berpengaruh terhadap kualitas audit di BPPKAD Sumenep. Hal ini tidak sejalan dengan teori yang dikemukakan oleh Yendrawati. Ketidak sejalanan ini mungkin karena Standar yang telah ditetapkan seharusnya ditaati oleh auditor dalam setiap penugasan audit agar tidak melenceng dari batas-batas yang telah ditetapkan sehingga tindak kecurangan dapat dihindari. Tuntutan auditor untuk bersikap profesional benar-benar dipacu sebagai pembuktian dari kredibilitas auditor. Klien dapat menekan kepada auditor untuk melawan standar profesional sehingga auditor tidak dapat bertahan dalam tekanan klien seperti menerima suap agar melakukan kecurangan. Hal ini telah melanggar standar profesi dan etika profesi yang telah ditetapkan.

Hasil penelitian ini juga tidak sejalan dengan hasil penelitian yang telah dilakukan oleh Restu Agusti bahwasannya profesionalisme mempunyai lima faktor penting, yaitu pengabdian pada profesi, kewajiban sosial, kemandirian, keyakinan terhadap profesi dan hubungan dengan sesama profesi. Dengan tingkat profesionalisme yang tinggi akan menghasilkan audit yang berkualitas tinggi.22

Dari hasil penelitian ini selaras dengan penelitian yang dilakukan oleh Fietoria dan Elisabeth Stefany yang menyatakan bahwa profesionalisme secara parsial tidak berpengaruh terhadap kualitas audit. Dimana kecermatan dan keseksamaan dalam penggunaan kemahiran profesional menuntut auditor untuk melaksanakan professional sceptism yaitu sikap auditor yang berpikir kritis terhadap bukti audit dengan selalu mempertanyakan dan melakukan evaluasi terhadap bukti audit. Auditor yang gagal dalam menerapkan sikap skeptis maka akan menghasilkan opini audit yang tidak berdaya guna dan tidak memiliki kualitas audit yang baik. ${ }^{23}$

Penelitian ini selaras juga dengan penelitian yang dilakukan oleh Putu Septiani futri yang menyatakan bahwa profesionalisme tidak berpengaruh terhadap kualitas audit. Untuk meningkatkan kualitas audit, seorang auditor dituntut agar bertindak profesional dalam melakukan pemeriksaan. Auditor yang profesional akan lebih baik dalam menghasilkam audit yang dibutuhkan dan berdampak pada peningkatan kualitas audit. Adanya peningkatan kualitas audit auditor maka meningkat pula kepercayaan pihak yang membutuhkan jasa profesional. Dengan demikian profesionalisme perlu ditingkatkan, karena sangat penting dalam melakukan pemeriksaan sehingga akan memberikan pengaruh pada kualitas audit auditor. Harapan masyarakat terhadap tuntutan transparasi dan

\footnotetext{
${ }^{21}$ Yendrawati, Reni. "Analisis Hubungan Antara Profesionalisme Auditor dengan Pertimbangan Tingkat Materialitas dalam Proses Pengauditan LaporanKeuangan.” Jurnal Fenomena, 1(2008) . hlm., 76.

${ }^{22}$ Restu Agust, Nastia Putri Pertiwi. "Pengaruh Kompetensi, Independensi dan Profesionalisme Terhadap Kualitas Audit". Jurnal Ekonomi, 3 (September 2013) hlm., 6.

${ }^{23}$ Fietoria, Elisabeth Stefany, "Pengaruh Profesionalisme, Independensi, Kompetensi, Dan Pengalaman Kerja Terhadap Kualitas Audit Di Kantor Akuntan Publik Bandung."Journal of Accounting and Business Studies, 1 (September, 2013) hlm., 33.
} 
akuntabilitas akan terpenuhi jika auditor dapat menjalankan profesionalisme dengan baik sehingga masyarakat dapat menilai kualitas audit. ${ }^{24}$

\section{b. Pengaruh indepedensi terhadap kualitas audit}

Pembahasan ini untuk menjawab dan menjelaskan tentang rumusan masalah, yaitu untuk mengetahui pengaruh independensi terhadap kualitas audit pada BPPKAD Sumenep. Maka dapat dijelaskan melalui poin pembahasan berikut ini:

Adanya pengaruh variabel independen $\mathrm{X}_{2}$ (independensi) terhadap variabel dependen $\mathrm{Y}$ (kualitas audit) dapat dilihat dari nilai koefisien regresi linier berganda bernilai positif yaitu 0.909. Hal ini berarti independensi $\left(\mathrm{X}_{2}\right)$ mempunyai hubungan yang positif terhadap kualitas audit, sehingga setiap terjadi peningkatan sebesar 1 satuan pada besaran independensi maka kualitas audit akan meningkat sebesar 0,909 atau 90,9\% dengan asumsi variabel - variabel yang lain dianggap tetap.

Independensi menurut Mulyadi adalah sikap mental yang bebas dari pengaruh, tidak dikendalikan oleh pihak lain, tidak tergantung pada orang lain. Independensi menurut Arens, Radal, Mark, \& Amir berarti cara pandang yang tidak memihak di dalam pelaksanaan pengujian, evaluasi hasil pemeriksaan dan penyusunan laporan audit.

Selanjutnya berdasarkan hasil analaisis uji t (secara parsial) diketahui variabel independensi $\left(\mathrm{X}_{2}\right)$ diperoleh $t_{\text {hitung }}$ sebesar 2,088 dengan taraf sig 0,047. Hasil uji tersebut menunjukkan bahwa nilai signifikan 0,047 $<0,05$ dan nilai $t_{\text {hitung }} 2,088>t_{\text {tabel }} 2,052$ maka dapat disimpulkan bahwa variabel indepedensi secara parsial berpengaruh terhadap kualitas audit dikarenakan Independensi merupakan syarat penting bagi auditor dalam melaksanakan prosedur audit yang bertujuan untuk menilai kewajaran laporan keuangan. Auditor dipercaya oleh pemakai laporan keuangan sebagai pihak independen untuk memberikan jaminan memadai mengenai asersi manajemen.

Penelitian ini selaras dengan penelitian lilis ardini yang menyatakan bahwa indepedensi berpengaruh terhadap kualitas audit. Dengan hal itu jika indepedensi sangat baik maka akan meningkatkan kualitas audit.Auditor berkewajiban untuk jujur tidak hanya kepada manajemendan pemilik perusahaan, namun juga kepada kreditur dan pihak lain yang meletakkan kepercayaan atas pekerjaannya. ${ }^{25}$

Penelitian ini juga sama dengan penelitian yang dilakukan oleh William Jefferson Wiratama dan Ketut Budiartha yang berarti bahwa hubungan antara independensi searah dengan pelaksanaan kualitas audit. Auditor dalam melaksanakan tugas audit, haruslah didukung dengan sikap independensi baik itu independen dalam fakta maupun independen dalam penampilan sehingga hasil audit menyatakan keadaan yang sebenarnya dan terbebas dari tekanan-tekanan dari pihak terkait. Hal terkait independensi ini juga diatur dalam standar

\footnotetext{
${ }^{24}$ Putu Septiani Futri, "Pengaruh Independensi, Profesionalisme, Tingkat pendidikan, Etika profesi, Pengalaman, Dan Kepuasan kerja auditor pada kualitas Audit Kantor Akuntan Publik di Bali."E-Jurnal Akuntansi, 7 (februari, 2014) hlm., 454.

${ }^{25}$ Lilis Ardini, "Pengaruh Kompetensi, Idenpendensi, Akuntabilitas dan Motivasi terhadap Kualitas Audit." majalah ekonomi, 3 (Desember, 2010) hlm., 347.

144
}

Shafin: Sharia Finance and Accounting Journal

Vol.1 No.2 September 2021 
umum kedua SPAP (2001) yaitu "Auditor harus mempertahankan sikap mental yang independen dalam semua hal yang berhubungan dengan audit". ${ }^{26}$

\section{c. Pengaruh kompetensi terhadap kualitas audit}

Pembahasan ini untuk menjawab dan menjelaskan tentang rumusan masalah, yaitu untuk mengetahui pengaruh kompetensi terhadap kualitas audit di BPPKAD Sumenep. Maka dapat dijelaskan melalui pembahasan berikut ini:

Adanya pengaruh variabel independen $\mathrm{X}_{3}$ (kompetensi) terhadap variabel dependen $\mathrm{Y}$ (kualitas audit) dapat dilihat dari nilai koefisien regresi linier berganda yaitu 0,333. Hal ini berarti kompetensi $\left(\mathrm{X}_{3}\right)$ mempunyai hubungan yang positif terhadap kualitas audit, sehungga setiap terjadi peningkatan sebesar 1 satuan pada besaran kepemimpinan maka kualitas audit akan meningkat sebesar 0,331 atau 33,1\% dengan asumsi variabel -variabel yang lain dianggap tetap.

Standar umum pertama dalam Standar Profesi Akuntan Publik (SPAP) menyebutkan bahwa audit harus dilaksanakan oleh seorang atau lebih yang memiliki keahlian dan pelatihan teknis yang cukup sebagai auditor. Standar ini diinterpretasikan sebagai keharusan bagi auditor untuk memiliki pendidikan formal di bidang auditing dan akuntansi serta mengikuti pendidikan profesional yang berkelanjutan.

Selanjutnya berdasarkan hasil analisis uji t (secara parsial) diketahui variabel kompetensi $\left(\mathrm{X}_{3}\right)$ diperoleh $\mathrm{t}_{\text {hitung }}$ sebesar 2,116 dengan taraf signifikan 0,044. Hasil uji tersebut menunjukkan bahwa nilai signifikan 0,044 $<0,05$ dan nilai $t_{\text {hitung }} 2,116>t_{\text {tabel }} 2,052$ maka dapat disimpulkan variabel kompetensi secara parsial berpengaruh terhadap kualitas audit BPPKAD Sumenep. Berpengaruhnya kompetensi terhadap kualitas audit disebabkan oleh semakin tinggi kompetensi yang dimiliki auditor, maka semakin tinggi pula kualitas audit yang dihasilkan oleh auditor. Standar umum pertama dalam SPAP menyebutkan bahwa audit harus dilaksanakan oleh seorang atau lebih yang memiliki keahlian dan pelatihan teknis yang cukup sebagai auditor.

Dari hasil penelitian ini selaras dengan penelitian yang dilakukan oleh Fietoria dan Elisabeth Stefany yang menyatakan bahwa kompetensi secara parsial berpengaruh terhadap kualitas audit. Karena seorang yang berkompeten adalah orang yang dengan mudah, cepat, intuitif dan sangat jarang atau tidak pernah membuat kesalahan. ${ }^{27}$

Penelitian ini juga selaras dengan penelitian yang dilakukan olehLauw Tjun Tjun dimana Sesuai dengan standar umum bahwa auditor disyaratkan memiliki pengalaman kerja yang cukup dalam profesi yang ditekuninya, serta dituntut untuk memenuhi kualifikasi teknis dan berpengalaman dalam bidang industri yang digeluti kliennya. Pengalaman juga akan memberikan dampak pada setiap keputusan yang diambil dalam pelaksanaan audit sehingga diharapkan setiap keputusan yang diambil adalah merupakan keputusan yang tepat. Hal tersebut mengindikasikan bahwa semakin lama masa kerja yang dimiliki auditor maka auditor akan semakin baik pula kualitas audit yang dihasilkan. ${ }^{28}$

${ }^{26}$ William Jefferson Wiratama dan Ketut Budiartha, "Pengaruh Independensi, Pengalaman Kerja, Due Professional Care Dan Akuntabilitas Terhadap Kualitas Audit." E-jurnal Akuntansi, 10 (januari 2015) hlm,. 101.

${ }^{27}$ Fietoria, Elisabeth Stefany, "Pengaruh Profesionalisme, Independensi, Kompetensi, Dan Pengalaman Kerja Terhadap Kualitas Audit Di Kantor Akuntan Publik Bandung." Journal of Accounting and Business Studies, 1 (September, 2013) hlm., 23

${ }^{28}$ Lauw Tjun, Elyzabet indrawati, santy setiawan, "Pengaruh Indepedensi dan Kompetensi AuditorTerhadap kualitas Audit."Jurnal Akuntansi, 1 (Mei, 2012) hlm., 53

Shafin: Sharia Finance and Accounting Journal

Vol. 1 No. 2 September 2021 


\section{Pengaruh profesionalisme, indepedensi dan kompetensi terhadap kualitas audit secara simultan.}

Pembahasan ini untuk menjawab dan menjelaskan tentang rumusan masalah, yaitu untuk mengetahui pengaruh profesionalisme, independensi dan kompetensi terhadap kualitas audit di BPPKAD Sumenep. Maka dapat dijelaskan melalui poin pembahasan berikut ini:

Hasil uji $\mathrm{F}$ menunjukkan bahwa nilai $\mathrm{f}_{\text {hitung }}$ sebesar 10,341 dengan tingkat signifikan sebesar 0,000 (lebih kecil dari signifikan 0,05). Sedangkan nilai $\mathrm{f}_{\text {tabel }} \mathrm{sebesar} 3,35$. Hal ini berarti bahwa nilai $\mathrm{f}_{\text {hitung }} 10,341>\mathrm{f}_{\text {tabel }} 3,35$ dan tingkat signifikan $0,000<0,05$, sehingga keputusannya adalah variabel X (profesionalisme, independensi, kompetensi) berpengaruh secara simultan terhadap kualitas audit di BadanPendapatan Pengelolaan Keuangan dan Aset Daerah Sumenep.

Menurut DeAngelo menyatakan bahwa kualitas audit terdiri atas dua komponen, yaitu kompetensi auditor dan Indepedensi auditor. Indepedensi dalam audit berarti mengambil sudut pandang yang tidak bias dalam melakukan pengujian audit, mengevaluasi hasilnya, dan membuat laporan audit.

Hal ini sesuai dengan penelitian yang dilakukan oleh Fietoria dan Elisabeth Stefanyyang menyatakan bahwa profesionalisme, Independensi dan kompetensi secara simultan berpengaruh terhadap kualitas audit.Auditor dalam melakukan tugas pemeriksaan harus memiliki sikap profesionalisme. Independensi, mempunyai kompetensi yang baik, dan memiliki pengalaman audit yang cukup agar dapat menghasilkan audit yang berkualitas. Profesionalisme dalam hal ini berkaitan dengan menjalankan tugas sesuai dengan bidang, mematuhi standar dan etika yang telah ditetapkan merupakan salah satu faktor yang penting dalam menghasilkan audit yang berkualitas. Sikap profesionalisme seorang auditor sangat berperan penting dalam pemeriksaan laporan keuangan perusahaan. Pernyataan ini sesuai dengan standar umum ketiga dalam SPAP yaitu dalam pelaksanaan audit dan penyusunan laporannya, auditor wajib menggunakan kemahiran.

\section{Seberapa besar pengaruh profesionalisme, independensi dan kompetensi terhadap kualitas audit}

berdasarkan tabel hasil Koefisien Determinasi $\left(\mathrm{R}^{2}\right)$ berdasarkan tampilan output SPSS 20 diperoleh sebesar 0,544 . Hal ini berarti $54,4 \%$ variasi dijelaskan oleh variasi dari ketiga variabel independen profesionalisme, independensi dan kompetensi. Sedangkan sisanya sebesar $(100 \%-54,4 \%=45,6 \%$ di jelaskan oleh sebab - sebab lain diluar model yang tidak diteliti dalam penelitian ini yaitu pengalaman kerja, akuntabilitas, Etika auditor, dan tingkat pendidikan.

\section{PENUTUP}

Berdasarkan hasil pembahasan, maka dapat ditarik kesimpulan (1) Variabel profesionalisme $\left(\mathrm{x}_{1}\right)$ diperoleh $\mathrm{t}_{\text {hitung }}$ sebesar $-0,573$ dengan taraf sig. 0,572. Hasil uji tersebut menunjukkan bahwa nilai $t_{\text {hitung }}-0,573>t_{\text {tabel }} 2,052$ dengan demikian variabel profesionalisme secara parsial tidak berpengaruh terhadap kualitas audit pada BPPKAD Sumenep. (2) Variabel

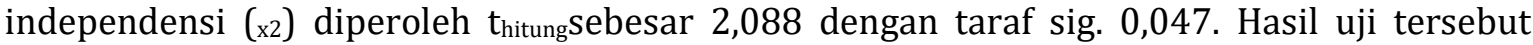
menunjukkan bahwa nilai signifikan $t_{\text {hitung }} 0,047<t_{\text {tabel }} 0,05$ dengan demikian, dapat disimpulkan bahwa variabel independensi secara parsial berpengaruh terhadap kualitas audit pada BPPKAD Sumenep.Dengan hal ini jika indepedensi sangat baik maka akan meningkatkan 
kualitas audit. (3) Variabel kompetensi $\left(\mathrm{x}_{3}\right)$ diperoleh $\mathrm{t}_{\text {hitung }}$ sebesar 2,116 dengan taraf sig. 0,044. Hasil uji tersebut menunjukkan bahwa nilai signifikan $t_{\text {hitung }} 0,044<t_{\text {tabel }} 0,05$ dengan demikian, dapat disimpulkan bahwa variabel kompetensi secara parsial berpengaruh terhadap kualitas audit pada BPPKAD Sumenep. (4) Hasil uji F diperoleh nilai $F_{\text {hitung }}$ sebesar 10,341 dengan tingkat signifikan $0,000<0,05$, sehingga keputusannya adalah variabel $\mathrm{X}$ (profesionalisme, independensi dan kompetensi) berpengaruh secara simultan terhadap kualitas audit pada BPPKAD Sumenep. Berpengaruhnya ke tiga variabel tersebut memberikan dampak positif bagi kualitas audit. Karena semakin tinggi kualitas audit maka akan mengasilkan laporan keuangan yang dapat dipercaya sebagai dasar pengambilan keputusan oleh pihak lain seperti investor.

Dari hasil analisis yang telah dilakukan dari pembahasan dalam penelitian ini maka saran yang bisa dikemukaan adalah: (1) Bagi pihak Badan Pendapatan Pengelolaan dan Keuangan Aset daerah dalam meningkatkan kualitas audit, seorang auditor dituntut agar bertindak profesional dalam melakukan pemeriksaan. Sikap profesionalisme yang rendah akan menumpulkan kepekaan auditor terhadap kecurangan baik yang nyata maupun yang berupa potensi atau terhadap tanda-tanda bahaya yang akan mengindikasikan adanya kesalahan dan kecurangan. Seorang Auditor lebih diharapkan lagi bersikap independen yaitu dapat bersikap netral serta menghindari konflik kepentingan dalam merencanakan, melaksanakan, dan melaporkan pekerjaan yang dilakukan. Hendaknya auditor terus-menerus menambah kemampuannya dalam pemahaman proses akuntansi, proses audit yaitu Standar Profesi Akuntan Publik (SPAP) maupun aturan lain yang berlaku di Indonesia. (2)Bagi peneliti selanjutnya perlu adanya pengembangan variabel-variabel yang dapat memperkaya faktorfaktor yang mempengaruhi kualitas audit selanjutnya agar variabel yang berpengaruh tersebut dapat ditingkatkan lagi kualitasnya.

\section{DAFTAR PUSTAKA}

Agusti, Restu dan Nastia Putri Pertiwi. "Pengaruh Kompetensi, Independensi dan Profesionalisme Terhadap Kualitas Audit". Jurnal Ekonomi No. 3 September 2013.

Ardini, Lilis. "Pengaruh Kompetensi, Independensi, Akuntabilitas Dan Motivasi Terhadap Kualitas Audit". Majalah Ekonomi Tahun XX, No. 3 Desember 2010.

Fietoria. "Pengaruh Profesionalisme, Independensi, Kompetensi, Dan Pengalaman Kerja Terhadap Kualitas Audit." Journalof Accounting and Business Studies Vol. 1, No. 1, September 2016.

Ghazali, Imam. Aplikasi Analisis Multivariate dengan Program SPSS. Semarang: Universitas Diponogoro, 2006.

Hasan, Iqbal. Analisis data Penelitian dengan Statistik. Jakarta: PT. Bumi Aksara, 2004.

Husein, Umar. Metodelogi Penelitian untuk Skripsi dan Tesis Bisnis. Jakarta: Rajawali, 2013.

Hery. 240 Konsep Penting Akuntansi Dan Auditing. Yogyakarta: Gava Media, 2013.

Indrawati, Elyzabet dan Lauw Tjun. Pengaruh Indepedensi dan Kompetensi AuditorTerhadap kualitas Audit, "jurnal Akuntansi" Mei, 2012.

Junaidi \& Nurdiono. Kualitas Audit. Yogyakarta: Andi Offset, 2016.

Junaidi \& Nurdiono.Kualitas Audit Perspektif Opini Going Concern. Yogyakarta: Andi Offset, 2016.

Kirana, Annisa Lucia.PengaruhProfesionalisme Auditor Terhadap Pertimbangan Tingkat Materialitas Laporan Keuangan (Pada Kantor Akuntan Publik Komisariat Wilayah Bandung). 2010. 
Kumaat, Valry G. Internal Audit. Jakarta: Erlangga, 2011.

Martono, Nanang. Metode Penelitian Kuantitatif. Jakarta: PT. Raja Grafindo Persada, 2012.

Mulyadi. Auditing Edisi 6. Jakarta: Salemba Empat, 2002.

Nachrowi, Djalal. Pendekatan Populer dan Praktis Ekonometrika Untuk Analisis Ekonomi dan Keuangan. Jakarta: Fakultas Ekonomi Univ Indonesia, 2006.

Siregar, Syofian. Metode Penelitian Kuantitati. Edisi Pertama, Cetakan ke-2, Jakarta: kencana, 2013.

Sugiyono. Metodologi Penelitian Bisnis: Pendekatan Kuantitatif, Kualitatif, dan R\&D. Bandung: Alfabeta, 2009.

Stefany, Elisabeth dan Fietoria. Pengaruh profesionalisme, Indepedensi, Kompetensi dan Pengalaman kerja terhadap Kualitas audit di kantor Akuntan Publik Bandung. Journal of Accounting and Business Studies Vol. 1, No. 1, September 2016.

Ulum, Ihyaul. Audit Sektor Publik. Jakarta:PT.Bumi Aksara, 2009.

Wibowo. Manajemen Kinerja. Jakarta: Rajawali Pers, 2013.

Yendrawati, Reni. Analisis Hubungan Antara Profesionalisme Auditor dengan Pertimbangan Tingkat Materialitas dalam Proses Pengauditan Laporan Keuangan". Jurnal Fenomena : Vol. 6 No.1, 2008.

Zuhrawati. Panduan dan Kiat Suksesmenjadi auditor ISO 9001. Yogyakarta: MediaPres, 2009. BKN, "perolehan oponi LKDP", LKDP, diakses dari http://www.dpr.go.id/dokakd/dokumen/BAKN-13 b8bff84bbea9634849ae1b25d29452a6.pdf, pada tanggal 7 September 2019 pukul 10.46 . 